\title{
PRODUCTION OF CARRAGEENAN BY DIFFERENT STRAINS OF Kappaphycus alvarezii CULTIVATED IN SERANG, INDONESIA
}

\author{
ANAS ZaKaria ${ }^{1}$, Egi NURUl RAHMAN ${ }^{1}$, Ulin NOOR RAHMANi ${ }^{1}$, Robert

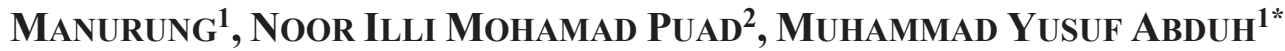 \\ ${ }^{1}$ School of Life Sciences and Technology, Institut Teknologi Bandung, \\ Jalan Ganesha No. 10 Bandung 40132 Indonesia \\ ${ }^{2}$ Bioprocess and Molecular Engineering Research Unit, \\ Department of Biotechnology Engineering, Kulliyyah of Engineering, \\ International Islamic University Malaysia, P.O. Box 10, 50728 Kuala Lumpur, Malaysia \\ *Corresponding author: yusuf@sith.itb.ac.id
}

(Received: 22 $2^{\text {nd }}$ January 2019; Accepted: $26^{\text {th }}$ June 2019; Published on-line: $2^{\text {nd }}$ December 2019)

ABSTRACT: Kappaphycus alvarezii is one of the main seaweeds cultivated in Indonesia. Its use as a raw material for the kappa-carrageenan industry has increased its cultivation activities. However, standard cultivation protocol for Kappaphycus alvarezii has yet to be well-documented, particularly on strain selection for kappa-carrageenan production. There are various strains of Kappaphycus alvarezii grown in Indonesia, specifically in Serang, Banten such as green, red, and yellowish green strains. In this study, growth rate, carrageenan yield, and gel strength from different strains of Kappaphycus alvarezii were investigated. It was observed that the specific growth rate of green type $(4.14 \%$ /day) differed significantly from the other two types (red; $3.41 \%$ /day and yellowish green; $3.47 \%$ /day). The red type had the highest yield of carrageenan $(45.16 \%)$ followed by yellowish green $(36.66 \%)$ and green strain $(33.67 \%)$. Gel strength was not significantly affected by the strain variations where the observed values for yellowish green, green, and red strain were 344.46, 316.91 and $313.10 \mathrm{~g} / \mathrm{cm}^{2}$, respectively. Green Kappaphycus alvarezii had the highest biomass $(0.27 \mathrm{~g} / \mathrm{cm} / \mathrm{d})$ and carrageenan productivity $(0.012 \mathrm{~g} / \mathrm{cm} / \mathrm{d})$. It can be concluded that the green strain of Kappaphycus alvarezii is the most suitable for cultivation in Serang, particularly for the kappa-carrageenan industry.

ABSTRAK: Kappaphycus alvarezii adalah sebahagian daripada rumpai air yang dituai di Indonesia. Penggunaannya sebagai bahan dasar kepada industri kappa-carrageenan telah menambah kepada aktiviti penuaian. Walau bagaimanapun, protokol penuaian biasa bagi Kappaphycus alvarezii adalah tertakluk pada dokumentasi penuh terutama dalam pemilihan strain pada penghasilan kappa-carrageenan. Terdapat pelbagai jenis strain Kappaphycus alvarezii yang tumbuh di Indonesia, terutama di Serang, Banten seperti hijau, merah, dan strain hijau kekuningan. Kajian ini, kadar pertumbuhan, hasil karaginan dan kekuatan gel daripada pelbagai strain Kappaphycus alvarezii telah dikaji. Didapati bahawa kadar pertumbuhan tertentu pada jenis hijau $(4.14 \% /$ hari $)$ berbeza ketara berbanding dari dua jenis lain (merah; 3.41\% /hari dan hijau kekuningan; 3.47\% /hari). Jenis merah mempunyai hasil karaginan tertinggi (45.16\%) diikuti oleh hijau kekuningan (36.66\%) dan strain hijau (33.67\%). Kekuatan gel adalah tidak ketara mempengaruhi kepelbagaian variasi di mana nilai yang dipantau pada strain hijau kekuningan, hijau dan merah adalah 344.46, 316.91 dan $313.10 \mathrm{~g} / \mathrm{cm}^{2}$, masing-masing. Kappaphycus alvarezii hijau mempunyai biojisim tertinggi $(0.27 \mathrm{~g} / \mathrm{cm} / \mathrm{d})$ dan penghasilan karaginan $(0.012 \mathrm{~g} / \mathrm{cm} / \mathrm{d})$. Kesimpulannya strain hijau Kappaphycus 
alvarezii adalah lebih sesuai untuk disemai di Serang terutamanya pada industri kappakaraginan.

KEYWORDS: Kappaphycus alvarezii; carrageenan yield; gel strength; productivity; specific growth rate

\section{INTRODUCTION}

Kappaphycus alvarezii belongs to the Rhodophyta group and its growing habitat is generally located at the top of the sub-territorial zone beneath the seawater tidal line on the rock or sand with moderate or medium speed ocean waves [1]. K. alvarezii has several strains that are distinguished mainly because of the difference in their color. It is the main source of kappa-carrageenan, a hydrocolloid that has been used extensively as an additive in various industries such as food, cosmetics, and pharmaceutical industries [2,3]. Carrageenan is a linear sulfated polysaccharide made up of a repeating disaccharide sequence of $\alpha$-D-galactopyranose linked 1,3 called the A residue and $\beta$-D-galactopyranose residues linked through positions 1,4 (B residues) that can be extracted from $K$. alvarezii [4].

K. alvarezii was firstly reported to be cultivated in the Philippines back in 1970 [5]. Then in the year 1985, with the increasing global demand for carrageenan, the cultivation of $K$. alvarezii made a debut in Indonesia [6]. Several factors, such as climate and weather conditions, ease, and low costs required for its cultivation have contributed to the vast amount of cultivation activities in Indonesia [7]. The three strains commonly cultivated in Serang, Indonesia are red, green, and yellowish green strains. However, there is still a lack of reports regarding the characteristics of carrageenan produced from these strains. This study aimed to determine the effect of strain variations towards the yield and gel strength of the extracted carrageenan. The results would assist the local community in selecting a strain yielding a good quality of carrageenan to be cultivated in Serang, Indonesia.

\section{MATERIALS AND METHODS}

\subsection{Cultivation of $K$. alvarezii}

The cultivation of $K$. alvarezii was carried out at Desa Lontar, Kecamatan Tirtayasa, Kabupaten Serang, Banten, Indonesia using the off-bottom method. The cultivation period in this study was set similar to the common practice in the field, namely 45 days. The cultivation parameters were: salinity of sea water ranging between $30 \mathrm{ppt}-33 \mathrm{ppt}$; average water temperature of $32^{\circ} \mathrm{C}$; sea water $\mathrm{pH}$ of 7.9-8.3; depth of sunlight penetration of 13.75 $\mathrm{cm}$ and received light intensity ranging between 59,100 - 62,400 lux. The shoots of vegetative growth of green, red, and yellowish green strains were obtained from Desa Lontar, Serang. About $30 \mathrm{~g}$ of seaweed fragments were tied on polyethylene (PE) ropes and the spacing between those fragments were 5,10 , and $15 \mathrm{~cm}$, respectively (Fig. 1). The rope was then mounted on the pile horizontally.

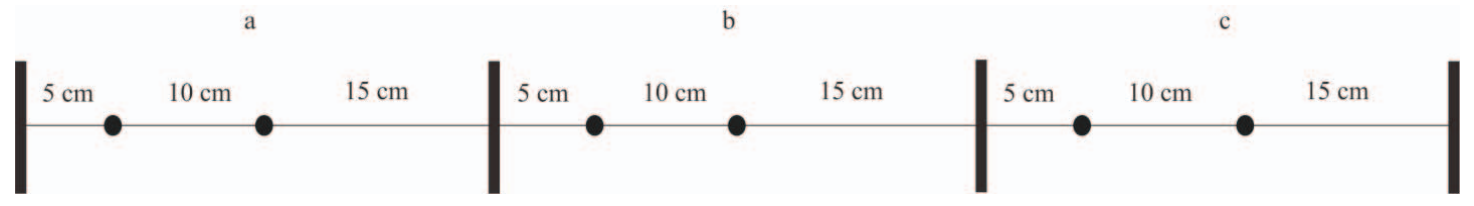

Fig. 1: Schematic diagram of $K$. alvarezii strains cultivation (a) green (b) yellowish green and (c) red with different spacing of seaweed fragments $(5 \mathrm{~cm}, 10 \mathrm{~cm}$ and 15 $\mathrm{cm})$. 
The fresh weight of each K. alvarezii strain was recorded every 7 days during the 45 days period of cultivation. The seaweed was then harvested after 45 days and the fresh weight was again measured. The growth rate (Eq. (1)) was then calculated according to Lignell and Pedersen [8].

$$
\text { Growth Rate }(\%)=\left[\left(\frac{W_{t}}{W_{i}}\right)^{\frac{1}{n}}-1\right] \times 100
$$

where $W_{t}=$ fresh weight after 45 days $(\mathrm{g}) ; W_{i}=$ initial fresh weight $(\mathrm{g}) ; n=$ cultivation period (45 days).

\subsection{Carrageenan Extraction}

Each strain of 45 days old $K$. alvarezii was sun-dried for 3 days until the water content reached $20-25 \%$. Extraction was carried out by adding $3 \mathrm{~g}$ of dried $K$. alvarezii to $4 \% \mathrm{NaOH}$ solution [9]. The process was carried out for 2 hours at $80{ }^{\circ} \mathrm{C}$ with continuous stirring. The extract was vacuum-filtered and the carrageenan was recovered from the solution by precipitation with $5 \% \mathrm{KCl}$ solution. The precipitate containing carrageenan was then again immersed in a $5 \% \mathrm{KCl}$ solution prior to washing with water. The extracted carrageenan was dried in an oven at $105^{\circ} \mathrm{C}$ until a constant dry weight was achieved. The yield of carrageenan extract was calculated using Eq. (2).

$$
\text { Yield }(\%)=\frac{\text { Dryweight of extracted carrageenan }(g)}{\text { Dryweight of K.alvarezii }} \times 100 \%
$$

\subsection{Carrageenan Extract Analysis}

The gel strength of extracted carrageenan was determined by dissolving $1.5 \%$ on a weight basis (w/w) of carrageenan in an aqueous solution at $90{ }^{\circ} \mathrm{C}$. The solution was then poured into a plastic tube (15 mm in diameter) and left at the room temperature for 3 hours [10]. The gel strength was analyzed using a TA-XT Plus Texture Analyzer (Stable Micro Systems, England) by applying a $2 \mathrm{~kg}$ maximum force using a $1 \mathrm{~cm}$ (diameter) cylindrical probe. The probe pressed the gel at a rate of $2 \mathrm{~mm} / \mathrm{s}$. Maximal penetration strength was considered as the gel strength, which was registered by the Texture Expert software (Stable Micro Systems Ltd., England). All analyses were conducted in triplicates.

\subsection{Estimation of Carrageenan Productivity}

The productivity of the cultivation process and carrageenan yield were determined based on the data of $10 \mathrm{~cm}$ cultivation spacing, 45 days cultivation time, as well as the growth rate and carrageenan yield for each K. alvarezii strain (Eq. (3)).

$$
P=\left(W_{t}-W_{i}\right) /(L x t)
$$

where $P=$ biomass productivity $(\mathrm{g} / \mathrm{cm} / \mathrm{d}) ; W_{t}=$ the final weight of biomass $(\mathrm{g}), W_{i}=$ weight of initial biomass $(\mathrm{g}), L=$ length of cultivation distance $(\mathrm{cm}), t$ is the cultivation time (d).

The estimation of carrageenan productivity was calculated using Eq. (4).

$$
C_{P}=Y \times M_{d} / t
$$

where $C_{P}=$ carrageenan productivity $(\mathrm{g} / \mathrm{cm} / \mathrm{d}) ; Y=$ carrageenan yield $(\%)$ and $M_{d}=$ mass of dried $K$. alvarezii after extraction with $25 \%$ of water $(\mathrm{g}), t$ is the cultivation time $(\mathrm{d})$. 


\subsection{Statistical Analysis}

All experiments in this study were carried out using a Completely Randomized Design with one main factor: variation of the K. alvarezii strain (green, red, and yellowish green). Each treatment was repeated three times (randomly). The data was processed using SPSS 23 for MacBook Pro at a 95\% confidence level.

\section{RESULTS AND DISCUSSION}

\subsection{The Growth of Different Strains of $K$. alvarezii}

The rate of biomass accumulation for $K$. alvarezii green strain for various cultivation spacing as shown in Fig. 2 implies that the spacing did not significantly affect its growth rate $(p>0.05)$. Similar observations were recorded for the red and yellowish green strains. Hence, $10 \mathrm{~cm}$ spacing was further used and discussed in this study since it is the common distance used by the seaweed farmers in the Serang area. The growth rate calculated using Eq. (1) was then compared with the strains grown in real conditions at Serang (Fig. 3). The calculated and observed values were in a good agreement with each other and it indicates that Eq. (1) can be used to estimate the rate of biomass accumulation of $K$. alvarezii.

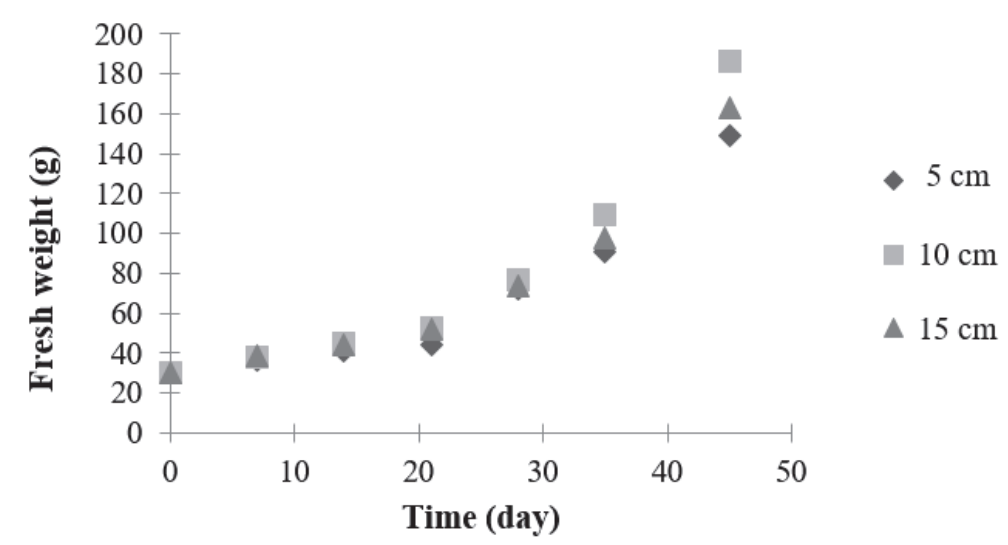

Fig. 2: Growth profile of $K$. alvarezii green strain at different cultivation spacing between seaweed fragments.

The green strain of $K$. alvarezii had the highest growth rate $(4.14 \%$ /day) compared to red $(3.41 \% /$ day) and yellowish green (3.47\%/day) strains (Fig. 4). The difference in terms of growth rate between the green strain and the other two strains were significant $(p$ $<0.05$ ). This result is similar with what has been reported by Munoz et al. [11] that green strain of $K$. alvarezii demonstrated a higher growth rate compared to the red strain. However, it was also reported that the red strain (3.8\%/day) achieved a slightly higher growth rate when compared to the green strain (3.4\%/day) [12]. Meanwhile for the red strain in this study, the growth rate was lower than reported by Munoz et al. [12], which ranged from $1.1 \%$ /day to $3.8 \% /$ day but below the range that has been reported by Hayashi et al. [2] (5.2-7.2\%/day). Overall, the values of $K$. alvarezii growth rate indicated that the Lontar village area, Serang is a suitable place to cultivate $K$. alvarezii. This is because its growth rate falls within the range of 3-5\%/day which is the standard value to specify a suitable cultivation areas for $K$. alvarezii [1]. 


\subsection{Carrageenan Yield and Gel Strength}

Carrageenan yield is one of the parameters observed in this study. This is because the yield of carrageenan from the $K$. alvarezii extraction process would directly affect its productivity and economic value. The yield of carrageenan extract for three strains of $K$. alvarezii is depicted in Fig. 5. The highest yield of carrageenan was produced by the red strain $(45.16 \%)$ whereas the carrageenan yield from green and yellowish green strains were $33.67 \%$ and $36.66 \%$, respectively. These values were higher than reported by Hayashi et al. [2] which ranged between $20-32 \%$ and were comparable with the range (8$30 \%$ ) reported by Valderrama et al. [13]. The difference in the yield of carrageenan for each strain was obvious, especially between the green and red strains (Fig. 5). This is possibly due to their pigment compositions. Each pigment has a different absorption rate for the color spectrum, which will eventually affect the main product of photosynthesis which is carrageenan [14]. The results of the ANOVA analysis suggest that strain variations had a significant effect on the carrageenan yield $((p<0.05)$.

Carrageenan properties, such as gel strength, have made carrageenan into an additive in various industries. In this study, the gel strength varied from $313.10-344.46 \mathrm{~g} / \mathrm{cm}^{2}$ (Fig. 6). The minimum gel strength was found in the carrageenan extracted from the red strain $\left(313.10 \mathrm{~g} / \mathrm{cm}^{2}\right)$ while the maximum one was produced by the yellowish green strain $\left(344.46 \mathrm{~g} / \mathrm{cm}^{2}\right)$. The results of the ANOVA analysis suggest that strain variations did not have a significant effect on the gel strength $((p>0.05)$.

The gel strength values were higher compared to the one reported previously which ranged from 3 to $112 \mathrm{~g} / \mathrm{cm}^{2}$ [15]. However, carrageenan gel strength in this study was lower compared to the carrageen quality standard set by the Food and Agriculture Organization (FAO) which lies in the range of 900 and $1200 \mathrm{~g} / \mathrm{cm}^{2}[16,17]$ as well as from the values reported by Basmal et al. [18] which lie in the range of $1029-1243 \mathrm{~g} / \mathrm{cm}^{2}$. Variations in the reported gel strength values might be due to different carrageenan extraction processes.

The yield and quality of carrageenan produced is not only influenced by the strains of seaweed that are being cultivated but also by several biological and environmental parameters such as plant age, light, nutrient, temperature, and salinity of the seawater [2, 19-24]. There could be other factors that contribute to the differences in the results achieved in this study with other reported results from studies conducted in different places.

\subsection{Comparison of Biomass and Carrageenan Productivity}

The biomass productivity was estimated based on the difference between the final and initial weight of $K$. alvarezii during 45 days of cultivation on polyethylene rope with a 10 $\mathrm{m}$ spacing between seaweed fragments. The cultivation was carried out for 45 days following the common practice in the field that the final weight of the biomass may have reached up to $400 \%$ of its initial weight [25]. It has been reported in a previous study that the highest biomass productivity of $K$. alvarezii was recorded after 44 days of cultivation, after which it started to decline when the cultivation period was prolonged to 59 days [2]. In another study, it is also reported that $K$. alvarezii that was cultivated for 45 days had a higher neutrophic activity than $K$. alvarezii that was harvested sooner (15 days) [26]. In this study, the percentage of biomass increase varies for all the three strains with the green strain having the highest percentage of biomass increase $(496 \%)$ followed by the yellowish green strain (349\%) and the red strain (337\%). 


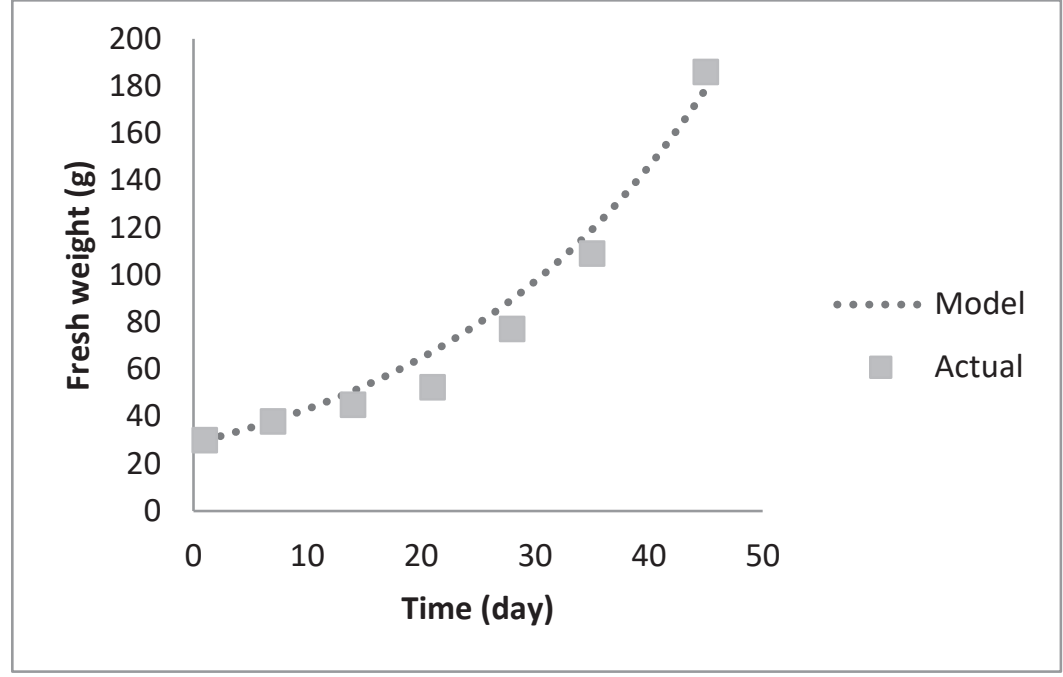

(a)

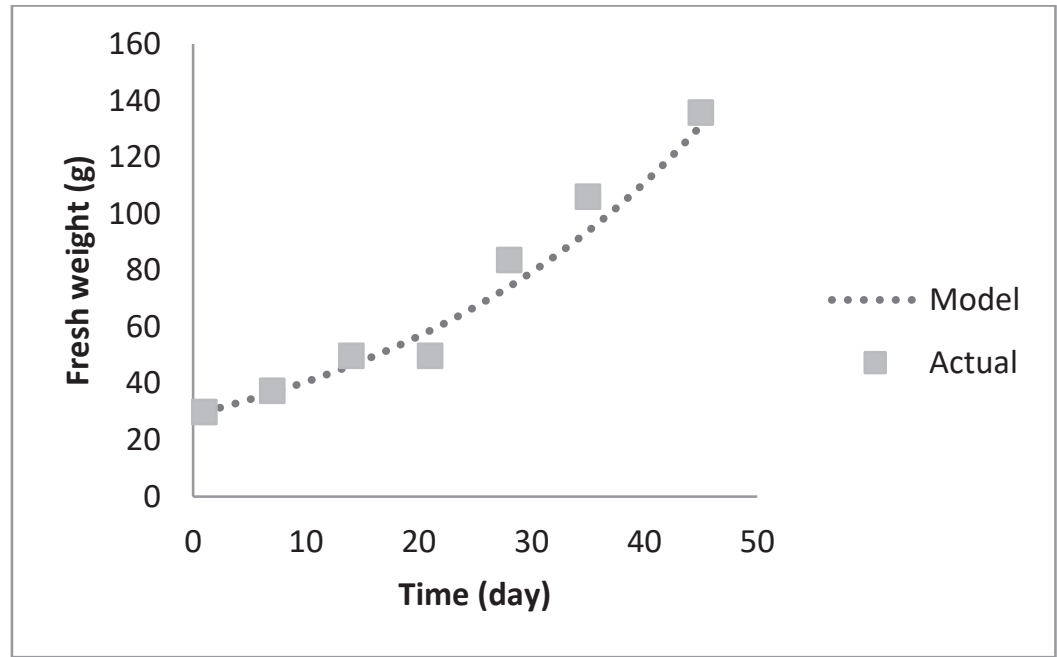

(b)

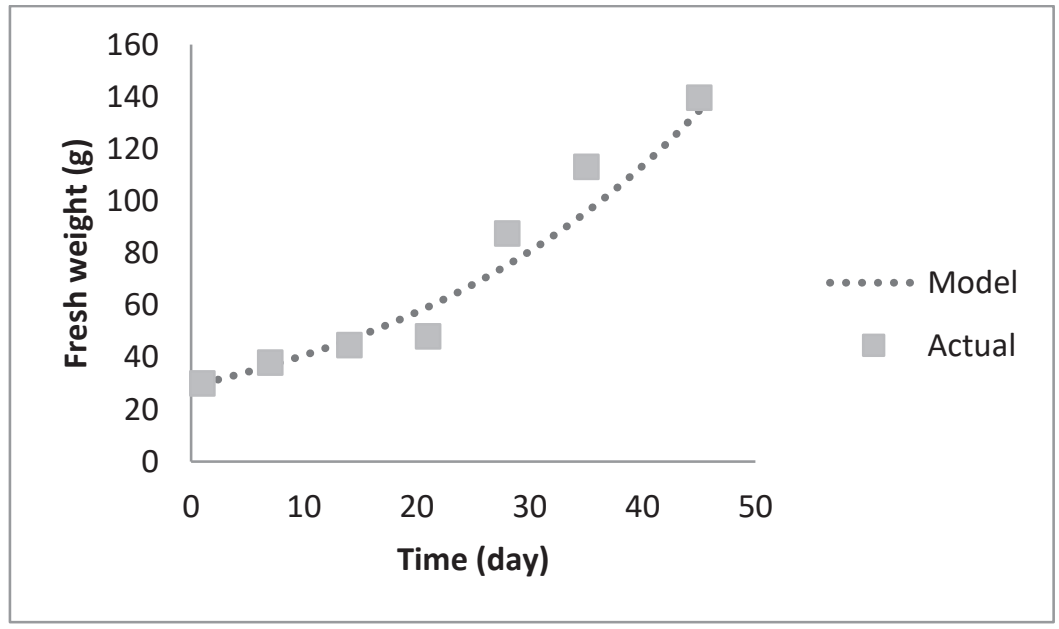

(c)

Fig. 3: Actual and modelled biomass accumulation rate for various $K$. alvarezii strain (a) green, (b) red, (c) yellowish green strains. 


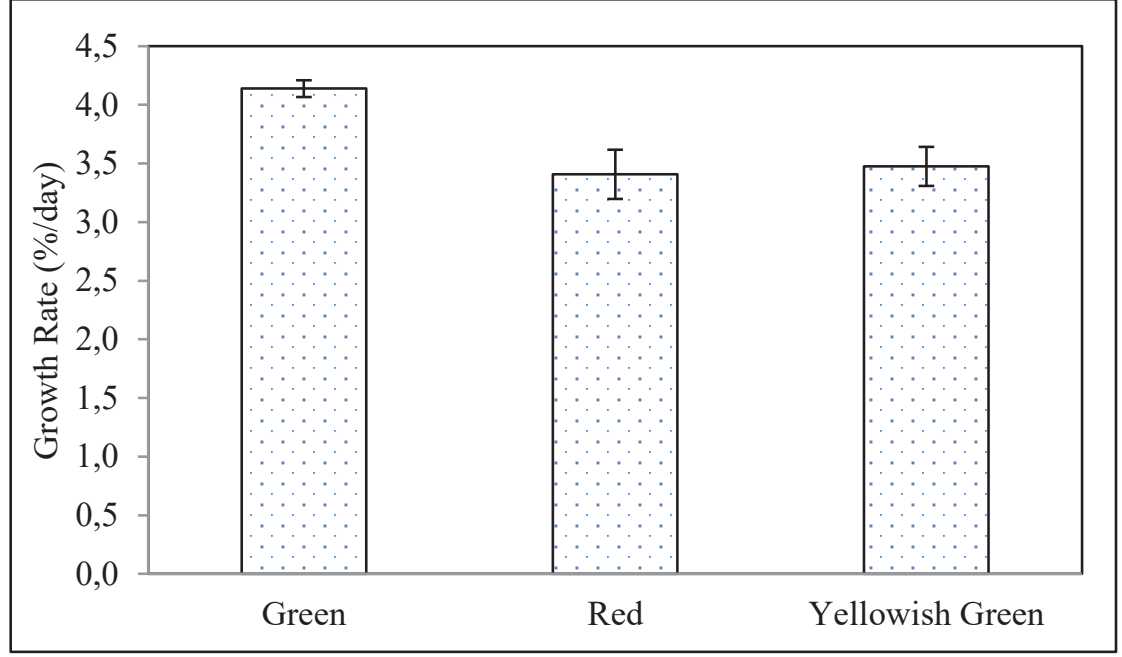

Fig. 4: Growth rate of $K$. alvarezii for different strain variations.

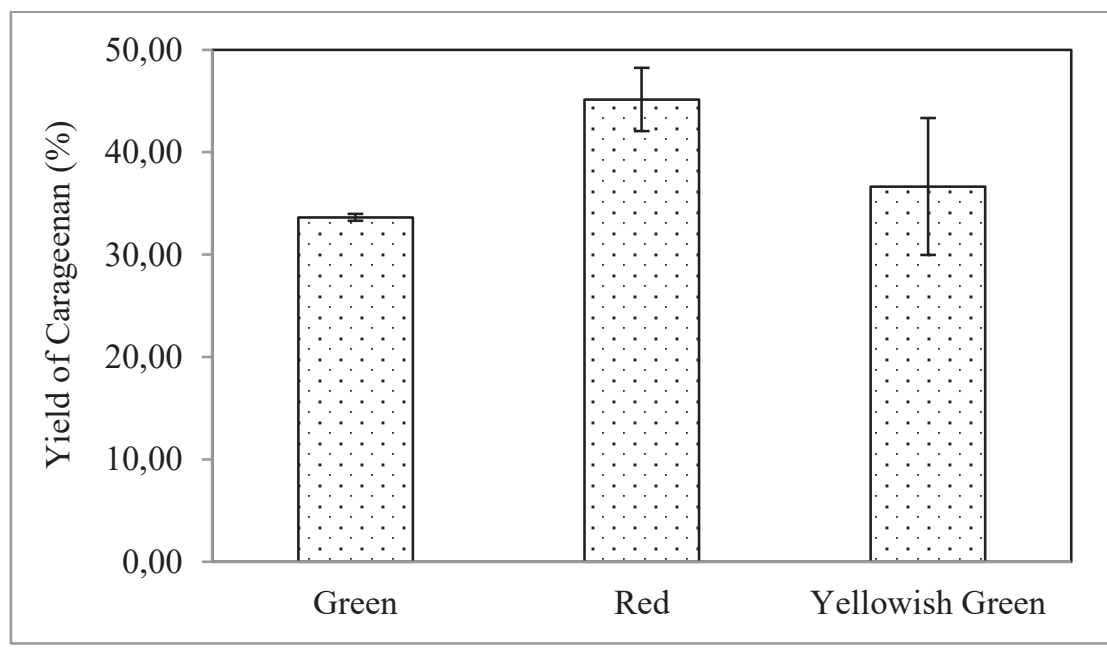

Fig. 5: Comparison of carrageenan yield for different strains of $K$. alvarezii.

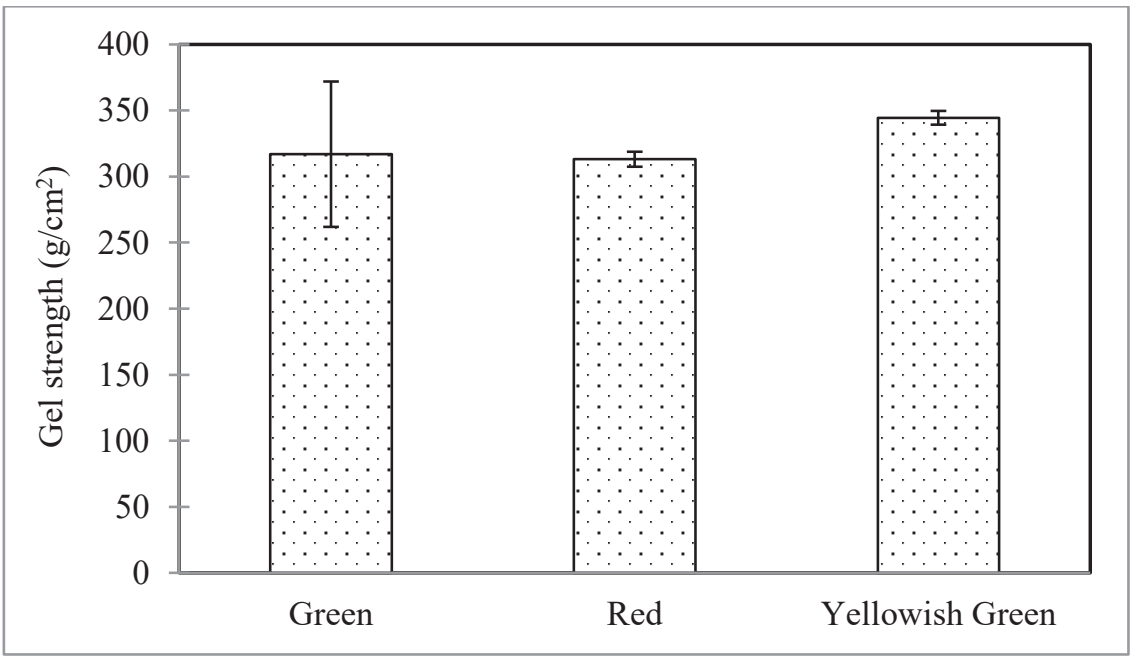

Fig. 6. Comparison of carrageenan gel strength for different $K$. alvarezii strains. There is no significant difference for each strain type. 
In a previous study on the cultivation of $K$. alvarezii using a longline method in Southwest Sulawesi, the biomass was cultivated for 40 days and recorded a percentage of biomass increase of $350 \%$ [27]. The study also compared a different cultivation technique, namely floating cage, and reported a higher percentage of biomass increase of $676 \%$. Several studies have reported the advantages of the floating cage method as compared to the longline method because it provides a protection to the seaweed from various herbivores and has a higher biomass productivity [27,28]. However, a longline method was used in this study due to the low depth of the cultivation area in Serang. Moreover, the longline method has been widely used by seaweed farmers in the Serang area for cultivating $K$. alvarezii.

Overall, the productivity of the green strain in terms of biomass and carrageenan was the highest among the strains (Table 1). The biomass productivity of the green strain was $0.27 \mathrm{~g} / \mathrm{cm} / \mathrm{d}$ while the red and yellowish green strains were $0.16 \mathrm{~g} / \mathrm{cm} / \mathrm{d}$ and $0.17 \mathrm{~g} / \mathrm{cm} / \mathrm{d}$. The results resemble the biomass productivity of $0.22 \mathrm{~g} / \mathrm{cm} / \mathrm{d}$ reported in a previous study for the cultivation of $K$. alvarezii using a longline method in Southwest Sulawesi [27]. Based on the yield of carrageenan obtained in the previous section, the estimated productivity of carrageenan in ascending order for yellowish green, red and green are $0.008,0.01$ and $0.012 \mathrm{~g} / \mathrm{cm} / \mathrm{d}$, respectively. Although several studies have reported the yield of carrageenan extraction process, studies that provide estimation on carrageenan productivity are still very scarce. Hence, the estimated carrageenan productivity reported in this study may provide useful information to produce carrageen from $K$. alvarezii.

Table 1: Productivity of $K$. alvarezii strains

\begin{tabular}{ccc}
\hline Strain & \multicolumn{2}{c}{ Productivity $(\mathrm{g} / \mathrm{cm} / \mathbf{d})$} \\
& Biomass & Carrageenan \\
\hline Green & 0.27 & 0.012 \\
Red & 0.16 & 0.010 \\
Yellowish green & 0.17 & 0.008 \\
\hline
\end{tabular}

\section{CONCLUSION}

In brief, variations of cultivation spacing between seaweed fragments did not affect the growth rate of $K$. alvarezii. On the other hand, different strains of $K$. alvarezii showed different growth rates and carrageenan yields. The green strain recorded the highest growth rate $(4.14 \%$ /day) while the highest carrageen yield $(45.16 \%)$ was produced by the red $K$. alvarezii strain. Green $K$. alvarezii had the highest biomass productivity $(0.27$ $\mathrm{g} / \mathrm{cm} / \mathrm{d})$ as well as carrageenan productivity $(0.012 \mathrm{~g} / \mathrm{cm} / \mathrm{d})$ compared to the other two strains. These observations can be used as a reference in selecting $K$. alvarezii strain to be cultivated in the area of Serang, Banten.

\section{REFERENCES}

[1] McHugh DJ. (2003) A Guide to the Seaweed Industry. Food and Agriculture Organization of the United Nations.

[2] Hayashi L, Oliveira EC, Bleicher-Lhonneur G, Boulenguer P, Pereira RTL, von Seckendorff R, Shimoda VT, Leflamand A, Vallée P, Critchley AT. (2007) The effects of selected cultivation conditions on the carrageenan characteristics of Kappaphycus alvarezii (Rhodophyta, Solieriaceae) in Ubatuba Bay, São Paulo, Brazil. Journal of Applied Phycology, 19: 505-511. 
[3] Masarin F, Cedeno FR, Chavez EG, de Oliveira LE, Gelli VC, Monti R. (2016) Chemical analysis and biorefinery of red algae Kappaphycus alvarezii for efficient production of glucose from residue of carrageenan extraction process. Biotechnology for biofuels, 9:122.

[4] Campo VL, Kawano DF, Silva DBd, Carvalho I. (2009) Carrageenans: Biological properties, chemical modifications and structural analysis $-\mathrm{A}$ review. Carbohydrate Polymers, 77(2): 167-180.

[5] Azanza-Corrales R, Sa-a P. (1990) The farmed Eucheuma species (Gigartinales, Rhodophyta) in Danajon Reef, Philippines: carrageenan properties. Hydrobiologia, 204(1): 521-525.

[6] Luxton DM. (1993) Aspects of the farming and processing of Kappaphycus and Eucheuma in Indonesia. Hydrobiologia, 260(1): 365-371.

[7] WWF-Indonesia TP. (2014) Better Management Practices (BMP)- Budidaya Rumput Laut Jenis Kotoni (Kappaphycus alvarezii), Sacol (Kappaphycus striatum), dan Spinosum (Eucheuma denticulatum). Indonesia: WWF-Indonesia.

[8] Lignell A., Pedersén M. (1989) Agar Composition as a Function of Morphology and Growth Rate. Studies on Some Morphological Strains of Gracilaria secundata and Gracilaria verrucosa (Rhodophyta). In: Botanica Marina; pp 219.

[9] Minghou J. (1990) Processing and extraction of phycocolloids. In: Report on the regional workshop on the culture and utilization of seaweeds (Vol. II) Bangkok, Thiland: NACA.

[10] Thrimawithana TR, Young S, Dunstan DE, Alany RG. (2010) Texture and rheological characterization of kappa and iota carrageenan in the presence of counter ions. Carbohydrate Polymers, 82(1): 69-77.

[11] Munoz J, Freile-Pelegrin Y, Robledo D. (2004) Mariculture of Kappaphycus alvarezii (Rhodophyta, Solieriaceae) color strains in tropical waters of Yucatan, Mexico Aquaculture, 239: 161-177.

[12] Hurtado-Ponce AQ. (1995) Carrageenan Properties and Proximate Composition of Three Morphotypes of Kappaphycus alvarezii Doty (Gigartinales, Rhodophyta) Grown at Two Depths. In: Botanica Marina, pp 215.

[13] Valderrama D, Cai J, Hishamunda N, Ridler N. (2013) Social and economic dimensions of carrageenan seaweed farming. In: Rome: Food and Agricultural Organizarion (FAO) Fisheries and Aquaculture Technical Paper, pp 217.

[14] Sunarto. (2008) Karakteristik biologi dan peranan plankton bagi ekosistem laut. Bandung: Universitas Padjajaran.

[15] Bono A, Anisuzzaman SM, Ding OW. (2014) Effect of process conditions on the gel viscosity and gel strength of semi-refined carrageenan (SRC) produced from seaweed (Kappaphycus alvarezii). Journal of King Saud University - Engineering Sciences, 26(1): 39.

[16] FAO. (2003) A Guide to The Seaweed Industry. Rome: FAO Fisheries Technical Paper.

[17] FAO. (2007) Carrageenan. FAO JECFA Monographs 4 2007; Prepared at the 68th JECFA.

[18] Basmal J, Ikasari D. (2014) Production of Semi Refine Carrageenan (SRC) from Fresh Kappaphycus alvarezii using Modified Technique with Minimum Use of Fuel Squalen Bulletin of Marine \& Fisheries Postharvest \& Biotechnology, 9(1): 17-24.

[19] Freile-Pelegrín Y, Robledo D. (2009) Carrageenan of Eucheuma isiforme (Solieriaceae, Rhodophyta) from Nicaragua. In: Nineteenth International Seaweed Symposium:

Proceedings of the 19th International Seaweed Symposium, held in Kobe, Japan, 26-31 March, 2007. Edited by Borowitzka MA, Critchley AT, Kraan S et al. Dordrecht: Springer Netherlands, pp 87-91.

[20] Glenn EP, Doty MS. (2001) Growth of the seaweeds Kappaphycus alvarezii, K. striatum and Eucheuma denticulatum as affected by environment in Hawaii. Aquaculture, 84(3):245-255.

[21] Hurtado AQ, Agbayani RF, Sanares R, de Castro-Mallare MTR. (2001) The seasonality and economic feasibility of cultivating Kappaphycus alvarezii in Panagatan Cays, Caluya, Antique, Philippines. Aquaculture, 199(3): 295-310.

[22] de Paula EJ, Pereira RTL, Ohno M. (1999) Strain selection in Kappaphycus alvarezii var. alvarezii (Solieriaceae, Rhodophyta) using tetraspore progeny. Journal of Applied Phycology, 11(1): 111-121. 
[23] Mendoza Wilson G, Ganzon-Fortes Edna T, Villanueva Ronald D, Romero Jumelita B, Montaño Marco Nemesio E. (2006) Tissue age as a factor affecting carrageenan quantity and quality in farmed Kappaphycus striatum (Schmitz) Doty ex Silva. In Botanica Marina, pp 57.

[24] Mulyani S, Tuwo A, Syamsudin R, Jompa J. (2018) Effect of seaweed Kappaphycus alvarezii aquaculture on growth and survival of coral Acropora muricata. AACL Bioflux, 11(6): 1792-1799.

[25] Kamlasi Y. (2008) Kajian Kajian Ekologis dan Biologi Untuk Pengembangan Budidaya Rumput Laut (Euchuema Cottonii) di Kecamatan Kupang Barat Kabupaten Kupang Nusa Tenggara Timur (Tesis). Sekolah Pascasarjana Institut Pertanian Bogor.

[26] Tirtawijaya G, Meinita MDN, Marhaeni B, Hazque MN, Moon IS, Hong YK. (2018) Neutrophic activity of the carrageenophyte Kapphycus alvarezii cultivated at different growth period in various areas of Indonesia. Evidence-Based Complementary and Alternative Medicine, 1-7.

[27] Kasim M, Mustafa A. (2017) Comparison growth of Kappaphycus alvarezii (Rhodophyta, Solieriaceae) cultivation in floating cage and longline in Indonesia. Aquaculture Reports, 6: 49-55.

[28] Kasim M, Mustafa A, Munier T. (2016) The growth rate of seaweed (Eucheuma denticulatum) cultivated in longline and floating cage. AACL Bioflux, 9(2): 291-299. 